A.L. Zelezinskii, O.V. Arhipova, D.V. Hodos, D.V. Parsukov

\section{METHODOLOGICAL APPROACHES TO ASSESSING AND FORMING PROSPECTS OF INNOVATIVE DEVELOPMENT OF THE REGIONS}

The article is devoted to the study of the problems of innovative development in the regions of the Russian Federation. The aim of this work was to determine the empirical relationship between the indicators of innovation activity, economic growth and the state of the institutional environment in the regions. For this purpose, the research methodology was formed and the analysis of the subjects of the Russian Federation was carried out with the establishment of current trends in innovative, institutional and economic development. The methodological basis of the study was the grouping method, the decision tree method, as well as economic and mathematical modeling for constructing production functions. In the course of the analysis, it was found that economic growth directly depends on the innovation and institutional factors. High values of these factors allow you to get GRP per capita at the level of 510 thousand rubles and above, with low values, this indicator is $180-200$ thousand rubles. The rate of economic growth is also directly proportional to these factors. It is also revealed that, first; the quality of public institutions and business institu-

\author{
А.Л. Зелезинский ${ }^{1}$, О.В. Архипова ${ }^{2}$, \\ Д.В. Ходос ${ }^{3}$, Д.В. Паршуков ${ }^{4}$
}

\section{МЕТОДИЧЕСКИЕ ПОДХОДЫ К ОЦЕНКЕ И ФОРМИРОВАНИЮ ПЕРСПЕКТИВ ИННО- ВАЦИОННОГО РАЗВИТИЯ РЕГИОНОВ}

Статья посвящена исследованию проблем инновационного развития в регионах РФ. Цель данной работы заключалась в определении эмпирической связи между показателями инновационной деятельности, экономическим ростом и состоянием институциональной среды в регионах. Для этого была сформирована методика исследования и проведён анализ субъектов РФ с установлением текущих тенденций инновационного, институционального и экономического развития. Методическую базу исследования составили метод группировки, метод дерева решений, а также экономикоматематическое моделирование для построения производственных функций. В ходе проведённого анализа установлено, что экономический рост прямо зависит от инновационного и институционального фактора. Высокие значения данных фракторов позволяют получать ВРП на душу населения на уровне 510 тыс. руб. и выше, при низких значениях этот показатель составляет 180-200 тыс. руб. Темпы экономического роста также имеют прямую пропорциональную зависимость от этих фракторов. Также выявлено, что в первую очередь качество общественных институтов и инсти-

\footnotetext{
${ }^{1}$ Зелезинский А.Л., доцент кафедры менеджмента и маркетинга, кандидат педагогических наук; Федеральное государственное бюджетное образовательное учреждение высшего образования "Санкт-Петербургский государственный технологический институт (технический университет)", г. Санкт-Петербург

Zelezinskii A.L., Associate Professor of the Department of Management and Marketing, PhD in Education; Federal State Budgetary Educational Institution of Higher Education "Saint-Petersburg State Technological Institute (Technical University)", Saint-Petersburg

E-mail: uchposob@yandex.ru

${ }^{2}$ Архипова О.В., профессор кафедры гостиничного и ресторанного бизнеса, доктор философрских наук, доцент; ФГБОУ ВО "Санкт-Петербургский государственный экономический университет", г. Санкт-Петербург

Arhipova O.V., Professor of the Department of Hotel and Restaurant Business, Doctor of Philosophy, Associate Professor; Federal State Budgetary Educational Institution of Higher Education "Saint-Petersburg State Technological Institute (Technical University)", Saint-Petersburg

E-mail: olva@list.ru

${ }^{3}$ Ходос Д.В., профрессор кафедры экономики и организации производства, доктор экономических наук, доцент; ФГБОУ ВО "Санкт-Петербургский государственный технологический институт (технический университет)", г. Санкт-Петербург

Hodos D.V., Professor of the Department of Economics and Organization of Production, Doctor of Economics, Associate Professor; Federal State Budgetary Educational Institution of Higher Education "Saint-Petersburg State Technological Institute (Technical University)", Saint-Petersburg

E-mail: hodos1@rambler.ru

${ }^{4}$ Паршуков Д.В., доцент кафедры организации и экономики сельскохозяйственного производства, кандидат экономических наук; ФГБОУ ВО "Красноярский государственный аграрный университет", г. Красноярск

Parsukov D.V., Associate Professor of the Department of Organization and Economies of Agricultural Production, $\mathrm{PhD}$ in Economics; Federal State Budgetary Educational Institution of Higher Education "Krasnoyarsk State Agrarian University", Krasnoyarsk

E-mail: parshukov83@mail.ru
} 
tions determines the effectiveness of development and the growth of innovation indicators at the regional level. The most significant attribute for the classification of subjects by the level of innovative development is the innovation activity index. It defines the current classification by $36.7 \%$, the indices of socio-economic conditions and the quality of innovation policy by $26 \%$. Macroeconomic modeling of economic growth in the regions depending on the level of innovative development is carried out, and the prospects for using the innovative factor as a driver of economic growth are evaluated. It is established that for a significant number of regions of the Russian Federation, the innovative way of development is not relevant in the medium term. Only for 15 territorial subjects of the Russian Federation, economic growth is real, accompanied by the development of innovative activities. Based on the results of the simulation, proposals are formulated for the directions of economic development of the regions. The article is intended for specialists and experts in the field of theory and practice of innovative development management at the regional level.

Keywords: innovative development, institutions, institutional environment, innovation, innovation activity, gross regional product, economic growth, classification, production functions, economic and mathematical modeling, socio-economic development. тутов ведения бизнеса определяет эффрективность развития и рост показателей инновационной деятельности на региональном уровне. Наиболее значимым атрибутом для классификации субъектов по уровню инновационного развития является индекс инновационной деятельности. Текущую классификацию он определяет на 36,7 $\%$, индексы социально-экономических условий и качества инновационной политики на $26 \%$. Проведено макроэкономическое моделирование экономического роста в регионах в зависимости от уровня инновационного развития, оценены перспективы применения инновационного фрактора как драйвера экономического роста. Установлено, что для значительного числа регионов РФ инновационный путь развития не является актуальным в среднесрочном периоде. Только для 15 субъектов РФ реальным является экономический рост, сопровождающийся развитием инновационной деятельности. По результатам моделирования сформулированы предложения по направлениям экономического развития регионов. Статья предназначена для специалистов и экспертов в области теории и практики управления инновационным развитием на региональном уровне.

Ключевые слова: инновационное развитие, институты, институциональная среда, инновации, инновационная деятельность, валовой региональный продукт, экономический рост, классификация, производственные функции, экономико-математическое моделирование, социально-экономическое развитие.

DOI: 10.36807/2411-7269-2021-2-25-51-59

\section{Introduction}

According to statistical reports, the indicators of innovative development in the Russian Federation and most of the subjects of the Russian Federation for the period 2013-2016 have a steady downward trend. Thus, the innovation activity of organizations decreased from $10.3 \%$ in 2013 to $8.4 \%$ in 2016. During the same period, the share of organizations engaged in technological innovations decreased from $9.1 \%$ to $7.3 \%$, and the share of innovative goods, works and services in the total volume of goods shipped, works and services performed decreased from $9.2 \%$ to $8.5 \%$ [1]. At the same time, the reduction of these indicators occurred annually during the entire designated period. It should be noted that now, the course adopted in 2010 on the transfer of the Russian economy to "innovative rails" has not led to the proper effects. At the same time, the analysis of the world economy in the post-crisis period from 2010 to the current time shows that innovation and the knowledge economy, human capital and intellectual assets remain the most important factor in the modernization and new industrial economy of Western countries [2]. The world economy itself is becoming less and less industrial, and at the same time, the role of peripheral territories and countries is increasing. One of the key factors of longterm growth of the national economy is recognized as the state stimulation of innovation activity [3].

The need for integrated approaches that combine the mechanisms of scientific, technical, industrial and innovative development is recognized in Russia, including at the level of 
Russian regions. The priorities in the current concept of economic development of the Russian Federation are "... economic growth and the sources of its diversification..." [4]. The main drivers of economic growth are investment, the growth of consumer consumption, effective demand, innovative technologies, and the development of human capital [4], [5], [6], [7]. It is noted that growth should be sustainable, above global values and accompanied by structural, technological and social modernization. An important role in the innovative development of the economy is assigned to individual regions. At the same time, there are foreign studies that empirically confirm the pattern of asymmetric and uneven development of innovation activity in different regions of the same state [8], [9]. These conclusions are also confirmed by Russian scientists [10, $11,12]$. Therefore, the question of whether all regions should follow the path of innovative development is open and debatable.

The analysis of the works carried out [4], [5], [6], [12], [13], [14] and our own research [15] on the problems of innovative development of regions allows us to identify the existing sustainable approaches aimed at forming an innovation policy, creating regional innovation systems and appropriate infrastructure. Despite the divergence of opinions on the tools and mechanisms for creating a sustainable model of regional development, most studies share the thesis that economic growth in the regions of the Russian Federation should be based on innovative technologies, the knowledge economy, and human resources. It is worth noting that the Nobel laureates D. North and R. Thomas wrote in 1973 in [16] that these factors (innovation, human capital, resource conservation, etc.) are not the causes of economic growth, but they are economic growth. The reasons for economic growth are the institutions and the institutional environment that promotes long-term planning, a favorable investment climate, the establishment of a clear specification of property rights and the reduction of frictional forces in the economytransaction costs.

Also in their study [17], F. Kiefer and M. Shirley, based on a comparison of countries, showed that the quality of public institutions is more important for economic development than the quality of economic policy. As A.A. Auzan points out, the challenges of economic growth in Russia are related to three factors: the search for sources of growth, the presence of institutional conditions, and the development of targets to clarify the economic course and directions of development [18]. In our opinion, it is very difficult to achieve innovative development without first forming a favorable institutional environment, since innovation requires not only an invention and an idea. A prerequisite is the availability of incentives for businesses to implement them. This also requires a long-term planning horizon, a clear legal framework with a specification and protection of the interests of production.

According to the authors, the innovative and socio-economic development of the Russian regions has been, and will remain, uneven. This is due to significant differences in economic potential, natural and climatic conditions, as well as differences in informal (supraconstitutional) institutions and the existing heterogeneous system of implementing formal rules. Therefore, the purpose of this work is to study the processes of economic growth in the regions of the Russian Federation and to assess the impact of innovative development and the quality of the institutional environment. The following questions are expected to be answered:

- If there is a connection between the achieved level of innovative development, the current quality of the institutional environment and indicators of economic growth in the regions of the Russian Federation;

- Under what conditions the growth of indicators of innovative development in the regions of the Russian Federation is achieved;

What the prospects for economic growth at the regional level are and whether all regions at this stage should follow the path of innovation and innovation promotion.

\section{Research data and methodology}

The study was conducted in several stages.

Stage 1. To determine the relationship between the level of innovative development and the state of the institutional environment, the method of grouping and logical analysis was used. The following grouping features were selected as the methodological and information base of the study:

A. Rating of innovative development of the regions of the Russian Federation from the Institute for statistical research and knowledge economics "Higher School of Economics". According to this rating, the regional innovation index (RII) consists of four sub-indices:

- $\quad$ index of socio-economic conditions of development (ISEC);

- $\quad$ science and technology capacity index (STCI); 
- $\quad$ innovation activity index (II);

- $\quad$ innovation policy quality index (IPQI).

Each index is calculated based on a set of corresponding indicators. The RII composite index combines information on 37 indicators. More information about the calculation method and the value of these indices for the regions can be found in the source [19].

According to the HSE methodology, in accordance with the rating, the regions of the Russian Federation are divided into 4 groups. For the event, the number of groups was reduced to three by simplifying the ranking as follows:

- $\quad$ regions from the first and second groups of innovative development were combined, and the value of the RII index greater than the minimum value for this group (0.38) will characterize the level of innovative development as "high" relative to other regions;

- $\quad$ regions with $\mathrm{RII}$ index in the range $(0.271 ; 0.38)$ are characterized by an average level of innovative development; vative development. regions with $\mathrm{RII}$ in the range $(0.1 ; 0.27)$ are characterized by a low level of inno-

The characteristics of the data array used for the selected rating are shown in Table 1.

Table 1 - Statistical characteristics of the initial array of HSE rating data

\begin{tabular}{|l|r|r|r|r|r|}
\hline \multicolumn{1}{|c|}{ Statistical parameter } & \multicolumn{1}{c|}{ IPQI } & \multicolumn{1}{c|}{ II } & \multicolumn{1}{c|}{ STCI } & \multicolumn{1}{c|}{ ISEC } & \multicolumn{1}{c|}{ RII } \\
\hline Maximum & 0,810 & 0,677 & 0,548 & 0,775 & 0,575 \\
\hline Minimum & 0,111 & 0,041 & 0,132 & 0,225 & 0,185 \\
\hline Medium & 0,394 & 0,276 & 0,312 & 0,381 & 0,337 \\
\hline Median & 0,382 & 0,270 & 0,301 & 0,361 & 0,331 \\
\hline
\end{tabular}

B. To assess the quality of the institutional environment, the National rating of the investment climate in the subjects of the Russian Federation, compiled by the Agency for Strategic Initiatives, was used [20]. The quality of the institutional environment was assessed based on the values of three areas from this rating - "Regulatory environment", "Quality of institutions for business", "Support for small businesses". In the initial rating, the subjects of the Russian Federation were divided into five groups. In this study, the following simplification was performed:

- $\quad$ the regions from the first group (leaders) and the second group (with comfortable business conditions), with the exception of the Republic of Mari El, the Chelyabinsk Region and the Orel region (for reasons of exclusion from the assessment of the direction "Infrastructure and resources"), are united in one group, and the quality of the institutional environment for them is set as "high".

- the Republic of Mari El, Chelyabinsk Region and Oryol region were added to the regions from the third group, and the quality of the institutional environment was established as " average»;

- the regions from the fourth and fifth groups are combined into one, and the quality of the institutional environment is set as "low" for them.

C. The following classical indicators were selected as characteristics of economic growth: GRP per capita and the average growth rate of GRP over the last three years. The average values of these indicators were calculated for each selected group.

All these indicators were selected for the last year of their calculation.

Stage 2. To determine the decisive rules and conditions for achieving certain levels of innovative development, the decision tree method based on the C4.5 algorithm was used [21]. To implement this algorithm, the Deductor analytical platform was used.

Stage 3. Assessment of the prospects for innovative development in the subjects of the Russian Federation.

To implement this stage, two types of functions were compiled for groups of regions divided by the level of innovative development in accordance with the HSE ratings:

1. Cobb-Douglas function according to the gross regional product (criterion variable), the value of fixed assets $(K)$ and the number of people employed in the economy $(L)$.

2. Production and innovation function:

$$
\mathrm{BP} \Pi=\mathrm{aZ}^{\delta} \mathrm{S}^{\varphi}
$$


where:

a - coefficient of expansion of aggregate impact of innovative factors;

$\mathrm{Z}$ - technological innovation costs, million rubles;

$\mathrm{S}$ - number of staff engaged in research and development, persons;

$\delta$ - elasticity of technological innovation costs;

$\varphi$ - elasticity of scientific work.

\section{Results and discussion}

The approaches and methods presented provided the following results and conclusions.

3.1 Results of the grouping of constituent entities of the Russian Federation

Using these two types of ratings and the grouping method, the regions of the Russian Federation were divided into nine groups (Table 2).

Table 2 - Preliminary grouping of regions of the Russian Federation

\begin{tabular}{|c|c|c|}
\hline $\begin{array}{l}\text { Level of innova- } \\
\text { tive development } \\
\text { (RII index (HSE)) }\end{array}$ & $\begin{array}{l}\text { Quality of institutional } \\
\text { environment (ASI rating) }\end{array}$ & Regions of the Russian Federation \\
\hline high & high & $\begin{array}{l}\text { Belgorod region, Voronezh region, Kaluga region, Moscow } \\
\text { region, Tambov region, Moscow, St. Petersburg, Republic of } \\
\text { Mordovia, Republic of Tatarstan, Chuvash Republic, Penza } \\
\text { region, Ulyanovsk region. Tyumen region. Tomsk region }\end{array}$ \\
\hline medium & high & $\begin{array}{l}\text { Murmansk region, Vladimir region, Kursk region, Oryol region, } \\
\text { Tula region, Leningrad region, Krasnodar region, Rostov re- } \\
\text { gion, Republic of Mari El, Kirov region, Kemerovo region, Chel- } \\
\text { yabinsk region }\end{array}$ \\
\hline high & medium & $\begin{array}{l}\text { Lipetsk region, Republic of Bashkortostan, Nizhny Novgorod } \\
\text { region, Samara region, Sverdlovsk region, Krasnoyarsk Territo- } \\
\text { ry }\end{array}$ \\
\hline high & low & $\begin{array}{l}\text { Stavropol Territory, Perm Territory, Novosibirsk region, Khaba- } \\
\text { rovsk Territory }\end{array}$ \\
\hline low & high & Kostroma region \\
\hline medium & medium & $\begin{array}{l}\text { Komi Republic, Sakha Republic (Yakutia), Kamchatka Territory, } \\
\text { Bryansk region, Ivanovo region, Yaroslavl region, Republic of } \\
\text { Karelia, Vologda region, Astrakhan region, Udmurt Republic, } \\
\text { Saratov region, Altai Territory, Primorsky Territory }\end{array}$ \\
\hline medium & low & $\begin{array}{l}\text { Ryazan region, Smolensk region, Tver region, Arkhangelsk } \\
\text { region, Novgorod region, Republic of Adygea, Volgograd re- } \\
\text { gion, Orenburg region, Kurgan region, Altai Republic, Republic } \\
\text { of Buryatia, Irkutsk region, Omsk region, Magadan region, Sa- } \\
\text { khalin region }\end{array}$ \\
\hline low & medium & Karachay-Cherkess Republic, Republic of Khakassia \\
\hline low & low & $\begin{array}{l}\text { Kaliningrad region, Pskov region, Republic of Kalmykia, Cri- } \\
\text { mea, Sevastopol, Republic of Dagestan, Republic of Ingushet- } \\
\text { ia, Kabardino-Balkarian Republic, Republic of North Ossetia - } \\
\text { Alania, Chechen Republic, Republic of Tuva, Trans-Baikal } \\
\text { Territory, Amur region }\end{array}$ \\
\hline
\end{tabular}

The largest group was formed by regions with a high (relative to other regions) level of innovative development and high quality of the institutional environment. This group includes 14 subjects of the Russian Federation, including 9 regions, 3 republics and two cities of federal significance. The next largest group (13 subjects each) is two groups. Both groups have a low quality of the institutional environment, but differ in the level of innovation development (low and medium). Another 22 subjects of the Russian Federation with an average level of innovative development formed two groups with high and low quality of the institutional environment, 12 and 11 subjects, respectively. Six subjects formed a group with a high level of innovative development and an average quality of institutions. There were also 2 microgroups, represented by two and one subjects.

According to the results of the grouping, it can be concluded that the subjects of the Russian Federation are characterized by five main ratios of the level of innovative development and the quality of the institutional environment, respectively: High-High, Medium-High, MediumMedium, Medium-Low, and Low-Low. The High-Low, Low-High, and Low-Average ratios are more of an exception to the rule. Thus, the higher quality of the institutional environment allows us to achieve higher indicators of innovative development of the economy of the subject of the 
Russian Federation. The worse the quality of public development and business institutions, the lower the innovation indicators and rating of the subject of the Russian Federation.

3.2 Results of comparison of the subjects of the Russian Federation on the values of the level of innovative development, the quality of the institutional environment and economic growth

The results of calculations of economic growth indicators for the selected groups are shown in Table 3.

Table 3 - Assessment of economic growth in the groups of subjects of the Russian Federation

\begin{tabular}{|c|c|c|c|c|c|c|c|c|}
\hline \multirow{2}{*}{$\begin{array}{r}\text { Quality } \\
\text { of IE }\end{array}$} & \multicolumn{2}{|c|}{ High } & \multicolumn{2}{|c|}{ Medium } & \multicolumn{2}{|c|}{ Low } & \multicolumn{2}{|c|}{$\begin{array}{c}\text { Total by criterion ID } \\
\text { Level }\end{array}$} \\
\hline & $\begin{array}{c}\text { Average } \\
\text { GRP per } \\
\text { capita for } \\
\text { the sub- } \\
\text { jects of the } \\
\text { Russian } \\
\text { Federation, } \\
\text { rubles }\end{array}$ & $\begin{array}{c}\text { Average } \\
\text { by sub- } \\
\text { jects } \\
\text { GRP } \\
\text { growth } \\
\text { rate,\% }\end{array}$ & $\begin{array}{c}\text { Average } \\
\text { GRP per } \\
\text { capita for } \\
\text { the sub- } \\
\text { jects of the } \\
\text { Russian } \\
\text { Federation, } \\
\text { rubles }\end{array}$ & $\begin{array}{c}\text { Average } \\
\text { growth } \\
\text { rate of } \\
\text { GRP by } \\
\text { subjects, } \\
\%\end{array}$ & $\begin{array}{c}\text { Average } \\
\text { GRP per } \\
\text { capita for } \\
\text { the sub- } \\
\text { jects of the } \\
\text { Russian } \\
\text { Federation, } \\
\text { rubles }\end{array}$ & $\begin{array}{c}\text { Average } \\
\text { growth } \\
\text { rate of } \\
\text { GRP by } \\
\text { subjects, } \\
\%\end{array}$ & $\begin{array}{c}\text { Average } \\
\text { GRP per } \\
\text { capita for } \\
\text { the sub- } \\
\text { jects of the } \\
\text { Russian } \\
\text { Federation, } \\
\text { rubles }\end{array}$ & $\begin{array}{c}\text { Average } \\
\text { growth } \\
\text { rate of } \\
\text { GRP by } \\
\text { subjects, } \\
\%\end{array}$ \\
\hline 1 & 2 & 3 & 4 & 5 & 6 & 7 & 8 & 9 \\
\hline High & 503083 & 109,74 & 401558 & 109,38 & 349752 & 109,70 & 452146 & 109,65 \\
\hline Medium & 321745 & 110,60 & 314949 & 110,09 & 301670 & 108,89 & 312419 & 109,83 \\
\hline Low & 241539 & 106,43 & 231943 & 107,19 & 184827 & 110,05 & 194261 & 109,47 \\
\hline $\begin{array}{l}\text { Total by } \\
\text { criterion } \\
\text { Quality } \\
\text { of IE }\end{array}$ & 412802 & 110,00 & 333561 & 109,56 & 257449 & 109,50 & 331668 & 109,69 \\
\hline
\end{tabular}

The general logic of the presented results is that a higher level of innovative development, combined with a higher quality of institutions, allows for higher indicators of economic growth. Thus, according to the data obtained, the highest value of the average GRP per capita is observed in the group of subjects with a high quality of the institutional environment and a high level of innovative development -503.08 thousand rubles. A decrease in the level of innovative development and / or the quality of the institutional environment necessarily leads to a decrease in economic growth indicators. Thus, while maintaining the level of innovative development at a higher level and reducing the quality of the institutional environment to an average state, the average GRP per capita also decreases to 401.6 thousand rubles. With a higher quality of the institutional environment and the average values of the innovation development index, the average GRP per capita is reduced from 503.08 thousand rubles to 321.75 thousand rubles. The indicated result confirms the presence of a direct relationship between the selected indicators.

In addition, based on the table presented, you can make a number of conclusions by analyzing the ratings separately. In regions with a higher comparative level of innovation development, the average GRP per capita is 452.15 thousand rubles and the average GRP growth is $109.65 \%$ per year, regardless of the quality of the institutional environment. At the same time, for regions with a high quality of the institutional environment, the average GRP per capita is 412,802 rubles with a growth rate of $110 \%$. This indicates that innovation activity in the region as a whole contributes to higher rates of economic growth than the quality of the institutional environment. At the same time, it is the quality of the institutional environment that contributes to more effective innovative development in the regions.

In general, GRP values per capita above the national average (331.67 thousand rubles) are observed in the subjects of the Russian Federation with the quality of the institutional environment at least average (the result according to the Quality of IE criterion in column 4) or a high comparative level of innovative development (the result according to the "ID Level" criterion and the "high").

3.3 Results of macroeconomic modeling of economic growth in the subjects of the Russian Federation

The characteristics of the Cobb-Douglas production functions are presented in Table 4, and the production and innovation functions in Table 5. 
Table 4 - Cobb-Douglas production functions for innovative classes of the Russian Federation subjects

\begin{tabular}{|c|c|c|c|c|c|}
\hline \multirow{2}{*}{ ID Level } & \multirow{2}{*}{$\begin{array}{l}\text { Formalization of the Cobb- } \\
\text { Douglas function }\end{array}$} & \multicolumn{2}{|c|}{ Capital elasticity } & \multirow[t]{2}{*}{ Scale effect } & \multirow{2}{*}{$\begin{array}{l}\text { Type of economic } \\
\text { growth }\end{array}$} \\
\hline & & $\mathrm{K}$ & $\mathrm{L}$ & & \\
\hline High & $\begin{array}{l}\mathrm{BP}=1,9 \cdot \mathrm{K}^{0,703} \cdot \mathrm{L}^{0,39} \\
\mathrm{R}=0,99 \\
\mathrm{~F}=561,44\end{array}$ & 0,703 & 0,39 & $K+L=1,097>1$ - Positive & Intensive \\
\hline Medium & $\begin{array}{l}\mathrm{BP}=4,84 \cdot \mathrm{K}^{0,66} \cdot \mathrm{L}^{0,33} \\
\mathrm{R}=0,97 \\
\mathrm{~F}=280,2\end{array}$ & 0,66 & 0,334 & $\begin{array}{l}\mathrm{K}+\mathrm{L}=0,994>1 \text { - } \\
\quad \text { Shrinking }\end{array}$ & Extensive \\
\hline Low & $\begin{array}{l}\mathrm{BP}=4,84 \cdot \mathrm{K}^{0,25} \cdot \mathrm{L}^{0,78} \\
\mathrm{R}=0,92 \\
\mathrm{~F}=63,2\end{array}$ & 0,24 & 0,77 & $\mathrm{~K}+\mathrm{L}=1,03>1$ - Neutral & Constant \\
\hline
\end{tabular}

Table 5 - Impact of innovation factors on economic growth

\begin{tabular}{|c|c|c|c|}
\hline \multirow[t]{2}{*}{ ID Level } & \multirow{2}{*}{ Production and innovation function } & \multicolumn{2}{|c|}{ Elasticity of factors } \\
\hline & & $\begin{array}{l}\mathrm{Z} \text { - the cost of techno- } \\
\text { logical innovation }\end{array}$ & $\begin{array}{c}\text { S-number of employees } \\
\text { engaged in research and } \\
\text { development }\end{array}$ \\
\hline High & $\begin{array}{l}\mathrm{BP}=351,2 \cdot \mathrm{Z}^{0,66} \cdot \mathrm{S}^{0,15} \\
\mathrm{R}=0,93 \\
\mathrm{~F}=68,8\end{array}$ & 0,6597 & 0,1483 \\
\hline Medium & $\begin{array}{l}\mathrm{BP}=5002,96 \cdot \mathrm{Z}^{0,248} \cdot \mathrm{L}^{0,31} \\
\mathrm{R}=0,82 \\
\mathrm{~F}=38,02\end{array}$ & 0,2481 & 0,316 \\
\hline Low & $\begin{array}{l}\mathrm{BP}=8982,2 \cdot \mathrm{Z}^{0,19} \cdot \mathrm{S}^{0,29} \\
\mathrm{R}=0,7 \\
\mathrm{~F}=6,34\end{array}$ & 0,188 & 0,29 \\
\hline
\end{tabular}

We will analyze the results obtained.

A. Regions with a low level of innovative development according to the HSE rating

The Cobb-Douglas function constructed for regions with a low level of innovative development indicates the presence of reserves for economic growth due to a proportional increase in the use of current factors of production: labor and the cost of production assets. At the same time, the elasticity of labor is more than three times higher than the elasticity of capital. Therefore, investment in human capital and increased labor productivity is a more promising source of economic growth in the medium term.

The type of production and innovation function indicates that the innovation factor is insignificant for the economic growth of these subjects of the Russian Federation. The expansion coefficient is a significant 8982.2. That is, to get the GRP value, the product of the elasticityadjusted values of these factors should be increased by 8982.2 times. The elasticity of scientific labor is higher than the cost of technological investment, which indicates its more significant role for GRP.

These regions are not ready for the activation of innovation activities. The prospects for the socio-economic development of such subjects of the Russian Federation will primarily depend on the size and quality of human capital, the increase in the economic potential of the ter- 
ritories, as well as the development of the institutional environment, rather than innovation. These are the main areas for economic growth in the medium term and they need to be developed individually. The transition to innovative development is possible only in the long term.

B. Regions with an average level of innovative development

The Cobb-Douglas function for regions with a comparative average level of innovation development has a decreasing effect of scale, that is, economic growth is more extensive. Such economies of scale indicate limited capacity to manage production processes and a lack of coordination of resource-output flows. Since the elasticity of capital is twice as high as the elasticity of labor, it is advisable to use the production factor and increase the capital intensity of regional production.

In accordance with the type of production and innovation function, the influence of the innovation factor on GRP is not decisive. At the same time, the expansion coefficient is lower than for regions with a low level of innovative development, but at the same time it is still quite large -5002.98 . The elasticity of scientific work is higher than the elasticity of costs for technological innovations, so the development of scientific potential is a higher priority in the medium term.

The regions of this class have almost fully utilized their own resource opportunities for economic growth, which means that the main directions of socio-economic development are seen in increasing the efficiency of capital through technical re-equipment and the development of human capital. Updating the main production assets, improving the skills of the labor used are the priority tasks. For the development of innovative processes, it is necessary to improve the institutional environment and increase the scientific and technical potential of the territories. The transition to innovative development is possible only in the medium term.

C. Regions are leaders in terms of innovative development

The Cobb-Douglas function indicates a positive effect of scale, which is characterized by intensive economic growth. Since the elasticity of capital is significantly higher than the elasticity of labor, investment in the modernization of production assets and the introduction of innovative technologies that increase the productivity of machinery and equipment is a priority. For the development of knowledge-intensive industries and the knowledge economy, it is necessary to develop the scientific and technical potential, as well as the material and technical base of scientific work, and to improve the quality of human capital.

The elasticity of the costs of technological innovation is higher than the elasticity of scientific work, and the type of production and innovation function itself indicates a stronger influence of these factors on GRP than for the other two classes of regions. Given the high quality of the institutional environment, these regions are ready for economic growth, accompanied by the development of innovative activities in the future 2-3 years.

\section{Conclusion}

Innovative development of the regions of the Russian Federation is extremely uneven. The conducted research shows that the activation of innovation activity is a logical continuation of economic growth, and not vice versa. The results also confirm the thesis that institutions have a strong influence on the effectiveness of creating and implementing innovations. There is a direct link between the level of innovative development, the quality of the institutional environment and the indicators of economic growth.

The transition to an innovative development path for a large number of regions of the Russian Federation is not an obvious solution to their socio-economic problems. For a significant number of regions, before embarking on such a step, it is necessary to pay attention to the state of the institutional environment and use current sources of development - to carry out technical re-equipment and modernization of existing production facilities, to improve the quality of human resources, to create conditions for the specification of intellectual property rights and legal protection of their own business. Innovation activity will be the next stage in the evolution of economic growth. At the same time, a number of regions are already ready to develop innovative activities on their territory in the near future. For this purpose, certain institutional, economic and infrastructural conditions have been created.

\section{References}

1. Индикаторы инновационной деятельности: 2017: статистический сборник / Н.В. Городникова, Л.М. Гохберг, К.А. Дитковский и др.; Нац. исслед. ун-т "Высшая школа экономики". - М.: НИУ ВШЭ, 2017. - 328 с. 
2. Татаркин А.И., Андреева Е.Л., Ратнер А.В. Императивы современного экономического развития: мировые тренды и российские реалии // Вопросы экономики. - 2014. - № 5. - C. 121-131.

3. OECD Publishing. The OECD Innovation Strategy: getting a head start on tomorrow. - OECD Pub., 2010.

4. Медведев Д.А. Социально-экономическое развитие России: обретение новой динамики // Вопросы экономики. - 2016. - № 10. - С. 5-30.

5. Сухарев О.С. Экономическая динамика: институциональные и структурные фракторы // М.: Ленанд. - 2015. - Т. 240.

6. Авраменко Ю.С. Условия и фракторы, влияющие на целевые установки инновационного развития региона // Фундаментальные исследования. - 2014. - № 6-2.

7. Сенникова И.Л., Снигирева Г.Д. Концептуальный подход к оценке инновационно-инвестиционного потенциала как важнейшего ресурсного фрактора развития региона // Вопросы региональной экономики. - 2015. - Т. 24. - №. 3. - С. 42-49.

8. Lau A. K. W., Lo W. Regional innovation system, absorptive capacity and innovation performance: An empirical study // Technological Forecasting and Social Change. - 2015. T. 92. - C. 99-114.

9. Doloreux D., Parto S. Regional innovation systems: Current discourse and unresolved issues // Technology in society. - 2005. - T. 27. - №. 2. - C. 133-153.

10. Буянова М.Э., Михайлова Н.А. Оценка дифференциации социальноэкономического развития регионов в инновационной стратегии России // Вестник Волгоградского государственного университета. Серия 3: Экономика. Экология. - 2017. - № $3(40)$.

11. Куценко Е.С., Нечаева Е.Г. Обзор зарубежных и отечественных исследований в сорере измерения инновационного развития регионов // Доклад на XV Апрельской Международной научной конференции по проблемам развития экономики и общества, 1-4 апреля 2014.

12. Мау В.А. Социально-экономическая политика России в 2014 году: выход на новые рубежи? // Вопросы экономики. - 2015. - № 2. - С. 5-31.

13. Борщ Л.М., Воробьёв Ю.Н., Герасимова С.В. Институциональная поддержка государственного инвестиционного и инновационного развития // Инновации и инвестиции. - 2015. - № 3. - С. 16-21.

14. Кравец А.В. Инновационная экономика России: проблемы и перспективы экономического роста // Креативная экономика. - 2016. - Т. 10. - № 1. - С. 21-34.

15. Parshukov D.V. et al. Tools for Assessment of Innovation Potential of the Business Environment Development in the Region // Biosciences Biotechnology Research Asia. - 2015. T. 12. - № 3. - C. 2983-2994.

16. North D.C., Thomas R.P. The rise of the western world: A new economic history. Cambridge University Press, 1973.

17. Keefer Ph., Shirley M.M. From the Ivory Tower to the Corridors of Power: Making Institutions Matter for Development Policy. Mimeo. World Bank, 1998. p. 31, 32.

18. Аузан А. и др. (ред.). Инновационное развитие экономики России: междисциплинарное взаимодействие. Сборник статей по материалам Седьмой международной научной конференции. - Litres, 2017.

19. Рейтинг инновационного развития субъектов Российской Федерации. Выпуск 5 / Г.И. Абдрахманова, П.Д. Бахтин, Л.М. Гохберг и др.; под ред. Л.М. Гохберга; Нац. исслед. ун-т "Высшая школа экономики". - М.: НИУ ВШЭ, 2017. - 260 с.

20. Агентство стратегических инициатив. - URL: http://asi.ru/investclimate/rating/ (дата обращения: 25.03.2017).

21. Michie D. et al. Quinlan, JR C4. 5: Programs for Machine Learning. - 1993. 